\title{
Ecology of ticks in a taxocenosis of snakes from the Serra do Mendanha, Rio de Janeiro, Brazil, with new host records
}

\author{
Jorge A. L. Pontes 1, 3; Gilberto S. Gazêta ${ }^{2}$; Davor Vrcibradic ${ }^{1} \&$ Carlos F. D. Rocha ${ }^{1}$ \\ ${ }^{1}$ Laboratório de Ecologia de Vertebrados, Departamento de Ecologia, Instituto de Biologia Roberto Alcantara Gomes, \\ Universidade do Estado do Rio de Janeiro. Rua São Francisco Xavier 524, Maracanã, 20550-011 Rio de Janeiro, Rio de \\ Janeiro, Brasil. \\ ${ }^{2}$ Laboratório de Ixodides, Departamento de Entomologia, Instituto Oswaldo Cruz. Avenida Brasil 4365, 21045-900 Rio de \\ Janeiro, Rio de Janeiro, Brasil. E-mail: gsgazeta@ioc.fiocruz.br \\ ${ }^{3}$ Corresponding author. E-mail: pontesjal@hotmail.com
}

\begin{abstract}
We studied the ecology of ticks found in different species of a taxocenosis of snakes from the Serra do Mendanha, an area of Atlantic Rainforest located in the state of Rio de Janeiro, southeastern Brazil. Snakes were sampled monthly in the field during a period of 48 months. The specific identity of the hosts and their parasites, the number of parasites, and and snout-vent length and body mass of each host were recorded. A total of $25 \%$ of the species of snakes in the area were parasitized by ticks (larvae, nymphs and adult females) Amblyomma rotundatum Koch, 1844 was the predominant parasite species. The infestation parameters varied among the species of snakes sampled, with the highest prevalence of $A$. rotundatum being observed in the viperid Bothrops jararaca (Wied, 1824) (71.4\%), followed by the colubrids Xenodon neuwiedii Günther, 1820 (33\%), Chironius laevicollis (Wied, 1824) and Spilotes pullatus (Linnaeus, 1758) (both with 22\%). The latter three species also showed the highest rates of infestation by $A$. rotundatum. The results of the present study suggest that a combination of skin shedding, habitat of the host, type of scale and pattern of scale distribution on the body of the host can influence the degree to which a given species is parasitized by ticks

KEY WORDS. Acari; Amblyomma rotundatum; Atlantic Rainforest; Ixodidae; Serra do Mendanha; snakes; ticks.
\end{abstract}

Information on Neotropical snake ectoparasitism by ticks and mites is still relatively scarce in the literature and usually involves data collected from snakes in captivity (e.g. MARA 1995, Amorim et al. 1996, Cubas 1997, Bush et al. 2002, MelgarejoGimenez 2002). Studies performed under natural conditions are rare (Lizaso 1984, Cunha et al. 2003, Dantas-Torres et al. 2005, PonTes \& Rocha 2008). When trying to understand the degrees to which certain species are affected and the reasons for the observed patterns, few studies evaluate parameters such as abundance, extent and prevalence of ectoparasitism in taxocenoses of snakes. In the present study, we analyze certain parameters of ectoparasitism in a taxocenosis of snakes from an area of the Atlantic Forest in the southeast of Brazil (state of Rio de Janeiro), in an attempt to understand how such ectoparasitism affects certain host species locally.

\section{MATERIAL AND METHODS}

Field collecting was performed by the first author in the Serra do Mendanha National Park (22 $48^{\circ}-22^{\circ} 51^{\prime} \mathrm{S}, 4^{\circ} 31^{\prime}-$ $\left.43^{\circ} 28^{\prime} \mathrm{W}, \mathrm{SAD} 69\right)$, located in the district of Rio de Janeiro, RJ. In this area of Atlantic Forest prevail forests in different levels of regeneration and low anthropic disturbance. The mean an- nual temperature ranges between 18 e $24^{\circ} \mathrm{C}$ and the annual precipitation ranges between 1200 e $2000 \mathrm{~mm}$. The highest temperatures and humidity levels happen between November and March (Clino 1996, Pontes \& Rocha 2008).

The snakes were sampled monthly from April 2002 to March 2006, totaling a sampling effort of approximately 800 hours/person. A combination of sampling methods was used that included intensive visual survey and pitfall traps with guides (CECHIN \& MarTins 2000). The total body and snout-vent length, and mass of each snake were recorded after anesthetizing the animal with ether. The entire body surface of each snake was then examined with the help of a magnifying lens $(5 x)$ for the presence of ectoparasites between and underneath the scales. All ectoparasites found were removed with a forceps, preserved in 50\% alcohol and latter identified in the laboratory with the help of taxonomic keys (ARAgão \& FonseCa 1961, Keirans \& Durden 1998, Amorim \& Serra-Freire 1999). All specimens of ectoparasites collected in this study were deposited in the collection of the Instituto Oswaldo Cruz (FIOCRUZ), under numbers Ixo 544 to Ixo 55. The terminology pertinent to parasitological ecology used in this paper follows Bush et al. (1997). 


\section{RESULTS}

During the 84-month period of this study, 191 individuals were captured, belonging to 24 distinct species of snakes distributed in four families: Boidae, Colubridae, Elapidae and Viperidae. However, only $8 \%(n=15)$ of the total number of individuals captured were parasitized (Tab. I). Out of the 24 species of snakes sampled, six (25\%) were parasitized exclusively by ticks: Chironius fuscus (Linnaeus, 1758), Chironius laevicollis (Wied, 1824), Spilotes pullatus (Linnaeus, 1758), Xenodon neuwiedii Günther, 1820, Bothrops jararaca (Wied, 1824) and Bothrops jararacussu Lacerda, 1884. Of these, the first four constitute new host records for the tick Amblyomma rotundatum Koch, 1844 (Ixodidae).

The ticks found in sampled snakes belong to two species: A. rotundatum and one unidentified species of Amblyomma Koch, 1844. The Brazilian Amblyomma are characterized by the presence of a conspicuous scutum with marginal eyes present; anal fault posterior to the anus and gnathosoma long (palps as long as the hypostome and cheliceras larger than base of gnathosoma, and second palpal article much longer than remaining articles) (Aragão \& Fonseca 1961, Serra-Freire 2001). Even though most Acari are apometabolic, some characters used in their diagnosis may vary depending on sex and developmental stage. Consequently, in order to identify adult females of A. rotundatum, we evaluated the presence of two short and rounded spurs on each of coxa II-VI; base of gnathosoma without prominent posterolateral angles; scutum with small to medium-sized punctations, more abundant laterally; hypostome with dentition 3/3 (with three rows of teeth on each side). Nymphs of $A$. rotundatum have two spurs on each of coxa II and III, internal spur small; hypostome rounded on anterior portion, hypostomal dentition 3/3; palps elongate; dorsal base of gnathosoma subquadrangular with rounded (not pointed) lateral margins; scutum with deep punctations along lateral margins (Keirans \& Durden 1998). The larvae are characterized by having coxa I with two spurs and each of coxa II and III with one spur; eyes with convex cornea; lateral portion of gnathosomal base rounded in dorsal view; sixth festoon wider than long; opisthosoma without dorsal rows of spines from the scutum to festoons III and VI; capsule of Haller's organ with axial and paraxial setae subequal, and antiaxial seta small, all of non-porous structure (Amorim \& SerRa-Freire 1999, Amorim et al. 2001).

Amblyomma rotundatum was the most common tick on parasitized snakes, corresponding to $99.1 \%(n=108)$ of the total sample size. Out of all ticks found on snakes, 55\% (n = $60)$ were nymphs, $2.2 \%(n=46)$ were larvae, and $1.8 \%(n=2)$ were adult females (Figs 1-3); the life stage of one $(n=1)$ individual $(0.9 \%)$ could not be determined. The latter specimen seems to belong to a different species which we were not able to identify, and is herein referred to as Amblyomma sp. Only the terrestrial and arboreal snakes were parasitized. Parasites were not found on fossorial, cryptozoic, semi-aquatic or aquatic snakes (Tab. I).
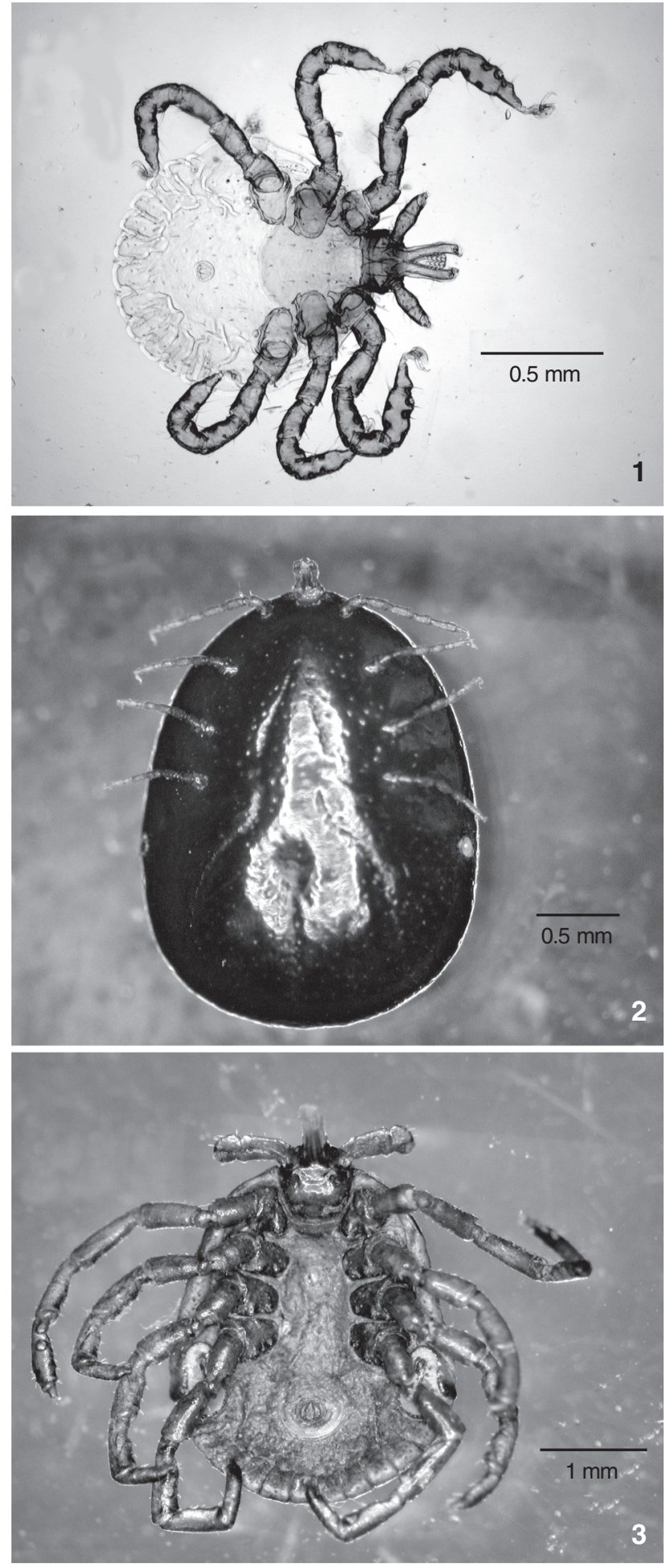

Figures 1-3. Life stages of $A$. rotundatum, ventral aspect: (1) larva; (2) nymph; (3) adult female. 
Table I. Species of snakes sampled from the Atlantic Forest, Serra do Medanha $(n=191)$, Rio de Janeiro, including their habits: (A) arboreal, (AQ) aquatic, (C) cryptozoic, (F) fossorial, (SA) semi-aquatic, (T) terrestrial; including location on the body of the host (L): (C) cephalic region, $(D)$ dorsal region, $(V)$ ventral region; and parameters of parasitism: $(P)$ prevalence, $(M A)$ mean abundance, $(\mathrm{MI})$ mean intensity.

\begin{tabular}{|c|c|c|c|c|c|c|c|}
\hline \multicolumn{3}{|l|}{ Snakes } & \multicolumn{5}{|c|}{ Ticks } \\
\hline Species & $\mathrm{n}$ & Habits & $\mathrm{n}$ & L & $\mathrm{P}(\%)$ & MA & MI \\
\hline \multicolumn{8}{|l|}{ Boidae } \\
\hline Boa constrictor Linnaeus, 1758 & 1 & $\mathrm{~T}, \mathrm{~A}$ & - & - & - & - & - \\
\hline \multicolumn{8}{|l|}{ Colubridae } \\
\hline Chironius bicarinatus (Wied, 1820) & 4 & $\mathrm{~T}, \mathrm{~A}$ & - & - & - & - & - \\
\hline C. exoletus(Linnaeus, 1758) & 5 & $\mathrm{~T}, \mathrm{~A}$ & - & - & - & - & - \\
\hline C. fuscus (Linnaeus, 1758) & 24 & $\mathrm{~T}, \mathrm{~A}$ & 1 & V & 4.2 & $0.04 \pm 0.20$ & 1 \\
\hline C. laevicollis (Wied, 1824) & 9 & $\mathrm{~T}, \mathrm{~A}$ & 29 & $\mathrm{D}$ & 22.2 & $3.20 \pm 7.40$ & $14.5 \pm 10.6$ \\
\hline C. multiventris Smith \& Walker, 1953 & 2 & $\mathrm{~T}, \mathrm{~A}$ & - & - & - & - & - \\
\hline Echinantera affinis (Günther, 1858) & 2 & $\mathrm{~T}, \mathrm{C}$ & - & - & - & - & - \\
\hline E. cephalostriata Di Bernardo, 1996 & 6 & $\mathrm{~T}, \mathrm{C}$ & - & - & - & - & - \\
\hline Elapomorphus quinquelineatus (Raddi, 1820) & 1 & $\mathrm{~T}, \mathrm{~F}$ & - & - & - & - & - \\
\hline Helicops carinicaudus (Wied, 1825) & 9 & $\mathrm{AQ}, \mathrm{SA}$ & - & - & - & - & - \\
\hline Leptophis ahaetulla (Linnaeus, 1758) & 6 & A & - & - & - & - & - \\
\hline Liophis miliaris (Linnaeus, 1758) & 32 & SA & - & - & - & - & - \\
\hline L. poecilogyrus (Wied, 1835) & 5 & $\mathrm{~T}$ & - & - & - & - & - \\
\hline Oxyrhopus petola (Linnaeus, 1758) & 4 & $\mathrm{~T}$ & - & - & - & - & - \\
\hline Philodryas olfersii (Lichtenstein, 1823) & 2 & $\mathrm{~T}, \mathrm{~A}$ & - & - & - & - & - \\
\hline Pseustes sulphureus (Wied, 1825) & 1 & $A, T$ & - & - & - & - & - \\
\hline Spilotes pullatus (Linnaeus, 1758) & 9 & $\mathrm{~T}, \mathrm{~A}$ & 33 & C, D & 22.2 & $3.70 \pm 9.50$ & $11.0 \pm 15.6$ \\
\hline Thamnodynastes nattereri (Mikan, 1828) & 22 & $\mathrm{~T}$ & - & - & - & - & \\
\hline Tropidodryas serra Schelegel, 1837 & 1 & $\mathrm{~T}$ & - & - & - & - & - \\
\hline Uromacerina ricardinii (Peracca, 1827) & 3 & $\mathrm{~T}, \mathrm{~A}$ & - & - & - & - & - \\
\hline Xenodon neuwiedii Günther, 1820 & 9 & $\mathrm{~T}$ & 50 & $\mathrm{D}, \mathrm{V}$ & 33.3 & $5.60 \pm 10$ & $16.7 \pm 11.2$ \\
\hline \multicolumn{8}{|l|}{ Elapidae } \\
\hline Micrurus corallinus (Merrem, 1820) & 25 & $\mathrm{~T}, \mathrm{~F}$ & - & - & - & - & - \\
\hline \multicolumn{8}{|l|}{ Viperidae } \\
\hline Bothrops jararaca (Wied, 1824) & 7 & $\mathrm{~T}$ & 3 & $C, D$ & 71.4 & $1.10 \pm 1.10$ & $1.6 \pm 1.1$ \\
\hline B. jararacussu Lacerda, 1884 & 2 & $\mathrm{~T}$ & 8 & $\mathrm{D}$ & 50.0 & $1.50 \pm 2.10$ & 3 \\
\hline Total & 191 & & 124 & & & & \\
\hline
\end{tabular}

Most ticks $(89 \%, \mathrm{n}=97)$ were found between the dorsal scales of the snakes; $5.5 \%(\mathrm{n}=6)$ were found between the scales on the top of the head; and $5.5 \%(n=6)$ were found underneath the ventral scales. The viperid $B$. jararaca showed the highest incidence of parasitism (prevalence $=71.4 \%$ ), followed by the colubrids X. neuwiedii (33\%), C. laevicollis and S. pullatus (both $22.2 \%$ ) (we did not consider B. jararacussu here because of the small $[\mathrm{n}=2]$ sample size). The latter three species also showed the highest mean values of infestation (X. neuwiedii:16.7 \pm 11.2 ; C. laevicollis: $14.5 \pm 10.6 ;$ S. pullatus: $11.0 \pm 15.6$ ). One individual of $C$. laevicollis which was maintained in captivity for four days had all of its ticks $(n=21)$ eliminated after shading the old skin.

We observed the highest rates of parasitism between the months of July and October. This period coincides partially with the lowest rates of snake findings and the lowest incidence of rainfall in the region (Figs 4 and 5) (PonTEs \& Rocha 2008). 

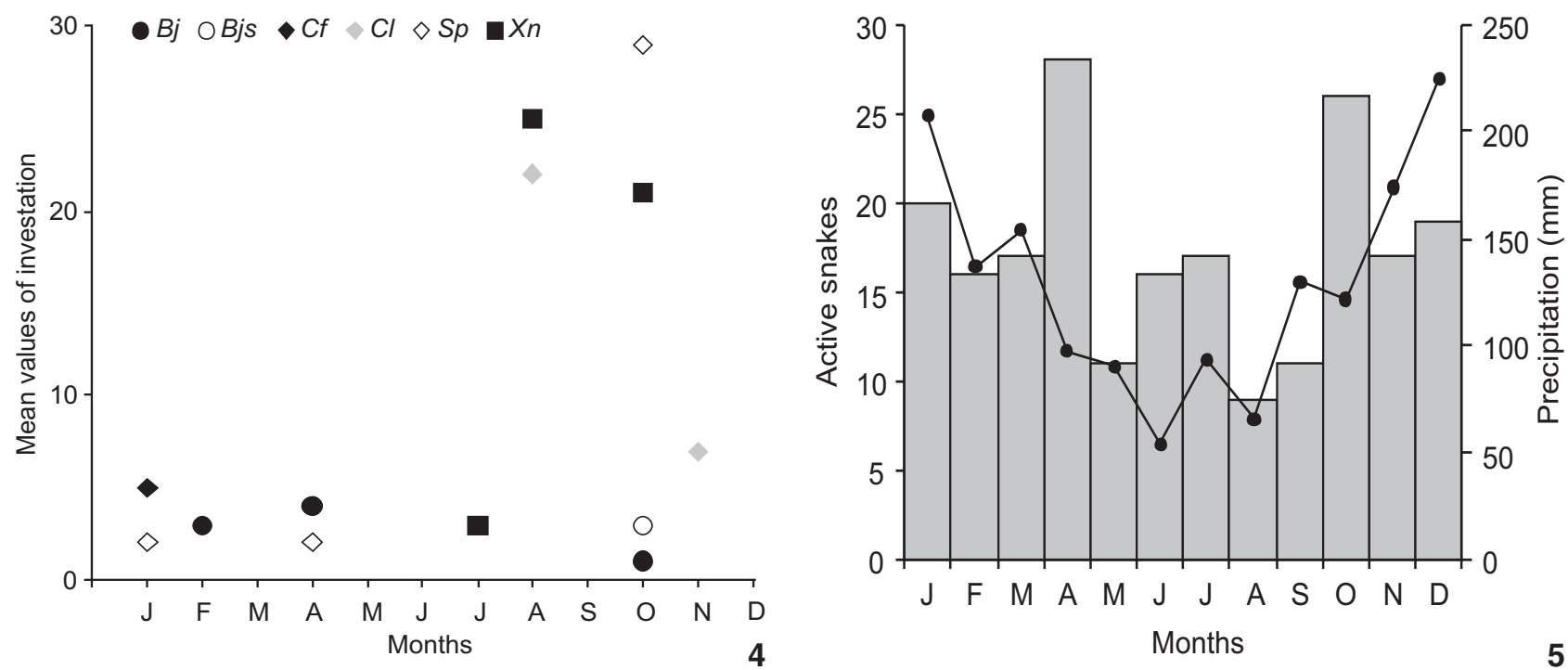

Figures 4-5. (4) Monthly rate of snake infestation by ticks in Serra do Mendanha, per species captured during this study; independent of year. (Bj) B. jararaca, (Bjs) B. jararacussu, (Cf) C. fuscus, (Cl) C. laevicollis, (Sp) S. pullatus, (Xn) X. neuwiedii; (5) total number of monthly encounters with active snakes in Serra do Mendanha (gray lines), regardless of species, and monthly precipitation in millimeters (dark lines).

\section{DISCUSSION}

Our results showed that relatively few species of snakes sampled from the Serra do Mendanha were parasitized by ticks (only 25\%), and in the great majority of the cases, by only one species (A. rotundatum). This suggests a broad utilization of different host species by only one species of ectoparasite along the year in this area. A. rotundatum is broadly distributed in the country, and has been found parasitizing snakes in different regions of Brazil (e.g. Aragão 1936, Dantas-Torres et al. 2005, Evans et al. 2000, LABRUNa et al. 2005).

Because the only additional species of Amblyomma found in this study was represented by a larva, we were not able to determine whether it belongs to Amblyomma dissimile Koch, 1844 (a species similar to A. rotundatum). Amblyomma rotundatum and $A$. dissimile are common parasites of amphibians and reptiles, and are both distributed in the Nearctic and Neotropical regions. Amblyomma dissimile, however, has a wider range of hosts (e.g. Doos et al. 1974, SerRa-Freire 2001, Botelho et al. 2002). Data by Aragão (1936) indicates that, even though these two species may have sympatric distribution, $A$. dimissile favors higher temperatures, what seems to be confirmed by reports from Evans et al. (2000). The biological characteristics of these two species allow for high adaptability to anthropic environments, but also indicate some variation in their ability to complete their respective biological cycles, particularly as a function of the kinds of hosts available (TeixeIRA et al. 2003). Even though there are records of males of $A$. rotundatum (Keirans \& Oliver 1993, Labruna et al. 2005), the low number of specimens recorded (three) and the teratogenic characteristics of at least one of them, lead us to question the importance of this stage in the life cycle of this species, believed to be parthenogenetic since 1912 (e.g. Aragão 1912, Aragão 1936, Oliver 1989, Serra-Freire 2001, Freitas et al. 2002, Hanson et al. 2007).

The results of this study suggest some variation in the levels of infestation displayed by the six species of parasitized snakes. These differences are probably a function of two factors: the differing patterns of scale distribution on the bodies of these species (which may or may not favor tick attachment); and the microhabitat utilized by the hosts. Studies performed on lizards suggest that the patterns of scale distribution are an important factor determining the degree to which different species are parasitized by the larva of Eutrombicula alfreddugesi (Oudemans, 1910) (Trombiculidae) (CARvalho et al. 2006, CunHABarros \& Rocha 2000, Cunha-Barros et al. 2003, rocha et al. 2008). On the other hand, it has also been shown that the type of habitat more frequently utilized by different species of lizards of the same genus (Mabuya) affect the degree to which each species is parasitised by E. alfreddugesi (CunHa-Barros \& Rocha 1995). Three of the species parasitized in this study (C. fuscus, C. laevicollis e $S$. pullatus) are semi-arboreal, whereas three others (X. neuwiedii, B. jararaca e B. jararacussu) are predominantly terrestrial (Marques et al. 2001, CAmpbell \& Lamar 2004, Pontes $\&$ Rocha 2008). The latter two species have keeled scales, contrasting with the remaining species, which have smooth scales. Despite these considerations, however, we cannot rule out the possibility of an association between the observed patterns of infestation and the seasonal patterns of snake activity in the region, which is higher in periods when precipitation is higher (Fig. 5). This could explain the high indexes of infestation ob- 
served for $X$. neuwiedii, which is most active during cold and dray periods, coinciding with the time when the larvae and nymphs of the ticks are dispersing (PONTEs \& Rocha 2008).

The absence ticks on snakes with cryptozoic and fossorial habits (Echinanthera affinis (Günther, 1858) (Colubridae), Echinanthera cephalostriata Di Bernardo, 1996 (Colubridae) and Micrurus corallinus (Merrem, 1820) (Elapidae) could be in part explained by the friction between the body and the substrate when the snake is burying, together with the smooth and juxtaposed scale pattern, what seems to make it difficult for the ticks to attach and remain attached. The absence of ticks on aquatic and semi-aquatic snakes may be explained by the fact that these parasites are terrestrial, and thus not adapted to aquatic environments.

The results of the present study suggest that a combination of skin shedding, type of scale, pattern of scale distribution on the body, and habitat can influence the degree to which a given species is parasitized by ticks.

\section{ACKNOWLEDGEMENTS}

We thank the Secretaria Municipal de Meio Ambiente, Rio de Janeiro, for granting us permits to conduct our research in the Serra do Mendanha National Park; the Ecology and Evolution graduate program, Universidade do Estado do Rio de Janeiro and the Instituto Biomas for their support. We also thank the park employees who helped us in many different ways, especially with the installation of Pitfall traps. Ronaldo Fernandes (Department of Vertebrate Zoology, Museu Nacional, Rio de Janeiro) confirmed the identification of the snakes collected for this study. CFDR received support from CNPq (process numbers 307653/2003-0 and 477981/2003-8) and from Fundação Carlos Chagas Filho de Amparo à Pesquisa do Estado do Rio de Janeiro (process E-26/100.471/2007).

\section{LITERATURE CITED}

Amorim, M. \& N.M. Serra-Freire, 1999. Chave dicotômica para identificação de larvas de algumas espécies do gênero Amblyomma Koch, 1844 (Acari: Ixodidade). Entomologia y Vectores 6 (1): 75-90.

Amorim, M.; G.S. Gazêta; R.S. Cristalli \& N.M. Serra-Freire. 1996. Biologia de Amblyomma rotundatum Koch, 1844 (Acari: Ixodidae) sob condições de laboratório: dinâmica da infestação de fêmeas não alimentadas em Crotalus durissus (L.). Revista da Universidade Rural, Série Ciências da Vida 18 (1-2): 35-39.

Amorim, M.; G.S. Gazêta \& N.M. Serra-Freire. 2001. Estudo do órgão de Haller de larvas de carrapatos do gênero Amblyomma (Acari: Ixodidae) do Brasil. Entomologia y Vectores 8 (1): 121-132.

Aragão, H.B. 1912. Contribuição com a systemática e biologia dos ixodideos. Memórias do Instituto Oswaldo Cruz 4: 96119.
Aragão, H.B. 1936. Ixodidas brasileiros e de alguns países limítrofes. Memórias do Instituto Oswaldo Cruz 36 (4): 759 843.

Aragão, H.B. \& F. FonsECA. 1961. Notas de Ixodologia. VIII. Lista e chave para os representantes da fauna ixodológica brasileira. Memórias do Instituto Oswaldo Cruz 59 (2): 115-129.

Botelho, M.C.N.; M.R.M. Leite; I.P. Bastos-Neto; L.A.M. Silva; M.L.C.B. Campello; M.C.A. Aguiar; N.M. Serra-Freire \& J. Bianque-De-Oliverra. 2002. Amblyomma dissimile Koch, 1844 (Acari, Ixodidae) em mamíferos silvestres no Estado de Pernambuco, Brasil. Entomologia y Vectores 9 (1): 71-78.

Bush, A.O.; K.D. Lafferty; J.M. Lotz \& A.W. Shostak. 1997. Parasitology meets ecology on its own terms: Margolis et al. revisited. Journal of Parasitology 83 (4): 575-583.

Bush, A.O.; J.C. Fernández; W.E. Gerald \& J.R. Seed. 2002. Parasitism: the diversity and ecology of animal parasites. Cambridge, Cambridge University Press, 566p.

Campbell, J.A. \& W.W. Lamar. 2004. The venomous reptiles of the western hemisphere. New York, Cornell University Press, vol. 1, p. 1-476), vol. 2, p. 477-774.

Carvalho, A.L.G.; A.F.B. Araújo \& H.R. Silva. 2006. Patterns of parasitism by Eutrombicula alfreddugesi (Oudemans) (Acari, Trombiculidae) in three species of Tropidurus Wied (Squamata, Tropiduridae) from Cerrado of habitat Central Brazil. Revista Brasileira de Zoologia 23 (4): 1010-1015.

Cechin, S.Z. \& M. Martins. 2000. Eficiência de armadilhas de queda (pitfall traps) em amostragens de anfíbios e répteis no Brasil. Revista Brasileira de Zoologia 17 (3): 729-740.

CLINo. 1996. Climatological Normals (CLINO) for the period 1961-1990. Geneve, World Meteorological Organization, 768 .

Cubas, Z.S. 1997. Cuidados veterinários com répteis em cativeiro, p. 49-65. In: L.R. Francisco (Ed.). Répteis do Brasil. Manutenção em cativeiro. São José dos Pinhais, Gráfica e Editora Amaro, 208p.

Cunha-Barros, M. \& C.F.D. Rocha. 1995. Parasitismo por ácaros Eutrombicula alfreddugesi (Trombiculidae) em duas espécies simpátricas de Mabuya (Sauria: Scincidae): o efeito do habitat na prevalência e intensidade parasitária. Oecologia Brasiliensis 1: 307-316.

Cunha-Barros, M. \& C.F.D. Rocha. 2000.Ectoparasitism by chigger mites (Eutrombicula alfreddugesi: Trombiculidae) in a restinga lizard community. Ciência e Cultura 52 (2): 108-114.

Cunha-Barros, M.; M.V. Sluys; D. Vrcibradic; C.A.B. Galdino; F.H. Hatano \& C.F.D. Rocha. 2003. Patterns of infestation by chigger mites in four diurnal lizard species from a restinga habitat (Jurubatiba) of southeastern Brazil. Brazilian Journal of Biology 63 (3): 393-399.

Cunha, M.C.A.L.; A.M.I. Farias; F.L.C. Brito \& N.M. Serra-Freire. 2003. Intensidade de parasitismo de Amblyomma rotundatum Koch, 1844 (Acari: Ixodidae) em serpentes da família Boidae capturadas no Parque Dois Irmãos, Recife, Pernambuco, Brasil. Entomologia y Vectores 10 (1): 21-29. 
Dantas-Torres, F.; E.F. Oliveira-Filho; B.O.F. Souza \& F.B. Sá. 2005. First records of Amblyomma rotundatum Koch, 1844 (Acari: Ixodidae) parasitizing Crotalus durissus cascavella (Wagler, 1824) (Squamata: Viperidae) in the state of Pernambuco, Brazil. Arquivos Instituto Biologia 72 (3): 389-390.

Doss, M.A.; M.M. Farr; K.F. Roach \& G. Anastos. 1974. Ticks and tickborne diseases - I: genera and species of ticks. Index Catalogue of Medical and Veterinary Zoology. Special Publication 3, Part 1. Washington, United States Department of Agriculture, 593p.

Evans, D.E.; J.R. Martins \& A.A.Guglielmone. 2000. A review of the ticks (Acari, Ixodida) of Brazil, their hosts and geographic distribution - 1. The State of Rio Grande do Sul, Southern Brazil. Memórias do Instituto Oswaldo Cruz 95 (4): 453-470.

Freitas, C.M.V.; R.C. Leite; C.M.L. Lopes; D.S. Rodrigues; G.F. Paz \& P.R. Oliverra. 2002. Lack of parthenogenesis by Amblyomma cajennense (Acari: Ixodidae). Memórias do Instituto Oswaldo Cruz 97: 843-846.

Hanson, B.A.; PA. Frank; J.W. Mertins \& J.L. Corn. 2007. Tick paralysis of a snake caused by Amblyomma rotundatum (Acari: Ixodidae). Journal of Medical Entomology 44: 155-157.

Keirans, J.E. \& L.A. Durden. 1998. Illustrated key to nymphs of the tick genus Amblyomma (Acari: Ixodidae) found in the United States. Journal of Medical Entomology 35 (4): 489-495.

Keirans, J.E. \& J.H. Oliver JR. 1993. First description of the male and redescription of the immature stages of Amblyomma rotundatum (Acari: Ixodidae), a recently discovered tick in the U.S.A. Journal of Parasitology 79: 860-865.

Labruna, M.B.; F.A. Terrassini \& L.M.A. Camargo. 2005. First report of the male of Amblyomma rotundatum (Acari: Ixodidae) from a Field-Collected Host. Journal of Medical Entomology 42:
945-947.

Lizaso, N.M. 1984. Fauna acarológica ectoparasita de serpentes não venenosas da região de construção de hidrelétricas (Sudeste, Centro-Oeste e Sul) do Brasil. Revista Brasileira de Zoologia 2 (2): 77-84.

Mara, W.P. 1995. Venomous snakes of the world. Neptune City, T.F.H. Publications, 224p.

Marques, O.A.V.; A. Eterovic \& I. Sazima. 2001. Serpentes da Mata Atlântica. Guia ilustrado para a Serra do Mar. Ribeirão Preto, Holos Editora, 184p.

Melgarejo-Giménez, A.R. 2002. Criação e manejo de serpentes, p. 175-199. In: A. Andrade; S.C. Pinto \& R.S. Oliveira (Eds). Animais de laboratório: criação e experimentação. Rio de Janeiro, Editora Fiocruz, 468p

Oliver, J.H. 1989. Biology and systematics of ticks (Acari: Ixodida). Annual Review of Ecology and Systematics 20: 397-430.

Pontes, J.A.L. \& C.F.D. Rocha. 2008. Serpentes da Serra do Mendanha, Rio de Janeiro, RJ: Ecologia e conservação. Rio de Janeiro, Technical Books Editora, 147p.

Rocha, C.F.D.; M. Cunha-Barros; VA. Menezes; A.F. Fontes; D. Vricibradic, \& M.V. Sluys. 2008. Patterns of infestation by the trombiculid mite Eutrombicula alfreddugesi in four sympatric lizard species (genus Tropidurus) in Northeastern Brazil. Parasite 15: 1-5.

Serra-Freire, N.M. 2001. Ácaros (Carrapatos e Outros). In: MarCONDES, C.B. Entomologia Médica e Veterinária. Rio de Janeiro, Editora Atheneu, 432p.

Teixeira, R.H.F.; M. Аmorim; G.S. Gazêta, \& N.M. Serra-Freire. 2003. Ixodofauna de répteis cativos no Zoológico de Sorocaba, São Paulo, Brasil. Entomologia y Vectores 10 (3): 319329.

Submitted: 08.VII.2008; Accepted: 11.VI.2009.

Editorial responsibility: Marcus V. Domingues 